\title{
Batasan Yuridis Perbuatan Melawan Hukum Dalam Operasi Intelijen Negara
}

\author{
Arif Yudha Febrianto, Zakiyyatul Mufidah \\ Fakultas Hukum Universitas Airlangga \\ rip.legalsaid@gmail.com
}

\begin{abstract}
In the past, the state intelligence agency in every intelligence activity was carried out without using clear legal norms. Limitation of authority in intelligence activities without regard to legal rules can cause violations of the rights of others. The purpose of this research is to understand how unlawfulness doctrine and can not be punished because a state intelligence operations. This research method is normative juridical with historical approach, statute approach, and conceptual approach. These results indicate that foreign intelligence operations are criminal acts regulated in Chapters 1-3, Book 2 of the Criminal Code. On the contrary, the Criminal Code protects state intelligence operations carried out by the state intelligence apparatus by reason of an official order in Articles 50 and 51 of the Criminal Code and Article 55 and 56 of the Criminal Code related to complicity. The duty of supervision of intelligence activities and intelligence agency in some other countries through the legislative and judicial body. The National Intelligence Act only regulates the institutional role so that it still requires a new draft law shall regulates intelligence activities which are subject by the law.
\end{abstract}

Keywords: intelligence, unlawfulness doctrine, crime

\begin{abstract}
Abstrak
Kegiatan intelijen yang dilakukan institusi intelijen negara pada masa lampau, secara umum dilakukan tanpa menggunakan norma hukum yang jelas. Batasan kewenangan dalam kegiatan intelijen tanpa memperhatikan aturan perundangundangan berdampak terhadap pelanggaran hak orang lain. Tujuan penelitian adalah mengetahui ajaran sifat melawan hukum dan tidak dapat dipidana suatu operasi intelijen negara. Metode penelitian adalah yuridis normatif dengan menggunakan metode pendekatan sejarah, perudangan-undangan dan konseptual. Hasil penelitian yang diperoleh yaitu operasi intelijen negara lain merupakan tindak pidana yang diatur dalam Bab 1-3, Buku ke-2 KUHP. Sebaliknya KUHP melindungi operasi intelijen negara yang dilakukan oleh aparat intelijen negara dengan dasar perintah jabatan dalam Pasal 50 dan 51 KUHP serta Pasal 55 dan 56 KUHP terkait penyertaan. Beberapa negara melakukan pengawasan aktivitas dan kelembagaan intelijen melalui badan legislatif dan yudikatif. Adapun UUIN hanya mengatur peran kelembagaan saja sehingga masih diperlukan RUU terbaru yang mengatur aktivitas intelijen yang tunduk oleh peraturan perundang-undangan.
\end{abstract}

Kata Kunci : Intelijen, Melawan Hukum, Tindak Pidana 


\section{Pendahuluan}

Referensi tentang pengumpulan informasi, kecerdasan menganalisa dan ke-waskita-an memilih opsi kebijakan dapat ditemukan dalam karya-karya sejarah. Aktivitas "matamata" merupakan salah satu kegiatan tertua yang salah satunya ditandai sejak Tuhan memerintahkan Nabi Musa untuk mengirim orang di tanah Kan'an. (FX Sutopo, 2008: 3). Menurut Shulsky dan Summit, kegiatan intelijen mengacu pada informasi yang relevan bagi formulasi dan implementasi kebijakan-kebijakan pemerintah untuk mengejar kepentingankepentingan kemanan nasional dan untuk menghadapi ancaman dari actual, potential and adversaries (Anggoro, 2002: 3). Pelaksanaan kegiatan intelijen harus tetap tunduk terhadap kaedah-kaedah hukum, supaya kegiatan tersebut tidak dianggap sebagai perbuatan melawan hukum. Sebagai contoh, tahun 1971

Badan Intelijen Amerika Serikat atau Central Inteligent Agency (CIA) melakukan operasi intelijen Phoenix Operation di Vietnam dengan cara melakukan pemerkosaan dan pembantaian massal yang menewaskan 20.000 (dua puluh ribu) Viet Cong. (Karjadi, 2009: 11) Keberadaan aktifitas Operasi intelijen asing di Indonesia, salah satunya ditandai dengan tertangkapnya pilot Allan Pope oleh Angkatan Perang Republik Indonesia (saat ini TNI) karena diduga mendanai gerakan Pemberontakan Rakyat Semesta (PRRI). (Baskara T Wardaya, 2006: 157-158) Semakin maraknya beberapa pemberontakan lain di daerah yang dicurigai merupakan operasi intelijen negara asing dibelakangnya, membuat Presiden Soekarno pada akhirnya mengeluarkan Penetapan Presiden No. 11 Tahun 1963 tentang Pemberantasan Kegiatan Subversi (PP 11/1963).

Munculnya PP 11/1963 menjadi "buah simalakama" bagi Pemerintah yang berkuasa dengan adanya Gerakan 30 September Partai Komunis Indonesia (Gestapu) yang justru mempengaruhi Pasukan Cakrabirawa untuk melakukan pembunuhan terhadap beberapa "Jenderal" di tubuh TNI-AD. Di satu sisi ingin melindungi kedaulatan 
negara dari pengaruh perang dingin, namun disisi yang lain pemerintah sendiri dalam hal ini Presiden Soekarno bertindak kontroversial dengan mengeluarkan kebijakankebijakan yang melemahkan kedaulatan negara itu sendiri. Sebelum adanya PP 11/1963, kegiatan intelijen yang dilakukan negara lain masuk dalam delik pidana dalam Bab 1-3 Buku ke-2 Kitab Undang-Undang Hukum Pidana (KUHP) yang dikategorikan sebagai kejahatan kemanan negara. Keberadaan PP 11/1963 semakin memperkuat kedudukan negara dalam hal ini pemerintah untuk melindungi kedaulatan dari tindak pidana yang menyangkut kemanan negara. Tahun 2011, pemerintah telah mengeluarkan Undang-Undang No. 17 Tahun 2011 tentang Intelijen Negara (UUIN). Namun UU ini pun, menurut hemat Penulis masih belum memberikan solusi terhadap tindakan aparat intelijen itu sendiri. Munculnya UUIN hanya bersifat pengaturan koordinasi kelembagaan, sedangkan batasan hukum kegiatan intelijen yang dilakukan oleh negara (pemerintah Indonesia) maupun dasar hukum pengawasan kelembagaan masih belum tercakup secara jelas.

\section{Metode Penelitian}

Nilai ilmiah suatu pembahasan dan pemecahan masalah terhadap isu hukum yang diteliti, sangat tergantung kepada cara pendekatan yang digunakan. Apabila pendekatan tidak tepat, maka esensi penelitian menjadi tidak akurat dan kebenarannya dapat digugurkan, sama halnya dengan penelitian hukum, dengan pendekatan berbeda, kesimpulannya pun akan berbeda. (Jhony Ibrahim, 2006 : 56) Beranjak dari hal tersebut, maka menjadi penting untuk diketahui dan dipahami beberapa pendekatan yang diperlukan dalam suatu penelitian hukum normatif.

Tipe penelitian yang digunakan dalam penelitian ini adalah jenis penelitian hukum normatif. Penelitian hukum yuridis normatif yaitu cara penulisan yang didasarkan pada analisis terhadap sistematika dan sinkronisasi peraturan perundang-undangan yang sesuai dengan permasalahan dalam 
penelitian ini. Penelitian hukum normatif ini adalah suatu prosedur dan cara penelitian ilmiah untuk menemukan kebenaran berdasarkan logika keilmuwan hukum dari segi normatifnya. (Johnny Ibrahim, 2006 : 108)

\section{Penelitian hukum ini} menggunakan beberapa pendekatan masalah antara lain Pendekatan Sejarah (Historical Approach) untuk mengetahui landasan terbentuknya hukum di masa lampau dalam pemahaman ada keterkaitan dengan hukum dimasa sekarang. Kedua, Pendekatan Perundang-Undangan (Statue Approach) untuk menjelaskan bahwa dalam penelitian hukum yuridis normatif, tema sentral penelitian aturan hukum itu sendiri. Terakhir, Pendekatan Konseptual (Conseptual Approach) untuk memunculkan objek-objek yang menarik perhatian dari sudut pandangan praktis dan sudut pengetahuan dalam pikiran dan atribut-atribut tertentu.

Bahan hukum merupakan bahan dasar yang akan dijadikan acuan atau rujukan dalam penulisan penelitian ini.
Bahan hukum primer merupakan bahan hukum yang bersifat autoritatif yang artinya memiliki otoritas sebagai bahan hukum utama. (Peter Mahmud Marzuki, 2005 : 141) Bahan hukum primer terdiri dari peraturan perundang-undangan, risalah sidang, catatan resmi atau risalah dalam pembuatan perundangundangan, putusan hakim dan putusan lembaga arbitrase. (Johnny Ibrahim, 2006 : 296)

Bahan hukum sekunder adalah bahan hukum yang berupa bukubuku referensi atau teks yang ditulis oleh para ahli hukum yang berpengaruh dan kasus-kasus hukum dari media-media informasi yang berkaitan dengan pembahasan. (Johny Ibrahim, 2006 : 296)

Bahan hukum tersier adalah bahan hukum yang memberikan penjelasan atau petunjuk terhadap bahan hukum primer dan sekunder yang berkaitan dengan bahan hukum tersier, misalnya kamus-kamus hukum dan ensiklopedi. 


\section{Hasil dan Pembahasan \\ Perkembangan Modus Operasi Intelijen Pertahanan dan Kemanan Negara}

Kegiatan intelijen memiliki pengertian lebih luas dibandingkan dengan operasi intelijen. Kegiatan intelijen adalah kegiatan mengumpulkan informasi, data, fakta, dan bahan keterangan baik secara terbuka maupun tertutup namun secara umum tertutup atau rahasia, sedangkan pengertian operasi intelijen itu sendiri merupakan kegiatan yang dilakukan berdasarkan suatu rencana untuk mencapai suatu tujuan khusus diluar tujuan rutin, ditetapkan dan dilaksanakan atas perintah yang berwenang. (Bab 1, Ketentuan Umum RUU Intelijen Negara) Perbedaan yang mendasar dari dua istilah tersebut terletak pada sasaran yang dicapai. Kegiatan intelijen memiliki suatu bentuk meliputi: (AC Manulang, 2001 : 48).
a) Sumber intelijen;
b) Propaganda;
c) Sabotase;
d) Kontra Sabotase:
e) Spionase; dan
f) Intelijen Pengamanan.

Sedangkan operasi intelijen yang pada dasarnya lingkupnya lebih sempit dan tertutup mempunyai lingkup dan kharakteristik: (AC Manulang, 2001: 25-31)
a) Subversi Asing;
b) Subversi Lokal;
c) Subversi Domestik dengan kekuatan asing;
d) Operasi Intelijen Terbuka (Positive Intelligence);
e) Operasi Intelijen Tersamar (Positive Clandestine Intelligence);

f) Penggalangan;
g) Kegiatan Tertutup (Covert Activity); dan

h) Kegiatan Rahasia Non-diplomat (Clandestine Activity).

\section{Kualifikasi Kegiatan Intelijen dalam KUHP}

Hukum pidana di Indonesia dibagi menjadi dua yaitu hukum pidana materil dan hukum pidana formil. Hukum pidana materil tercakup dalam KUHP sedangkan hukum pidana formil tercakup dalam aturan Undang-Undang No. 8 Tahun 1981 tentang Kitab Undang-Undang Hukum Acara Pidana. (Sudarto, 
1990: 8) Operasi intelijen yang dilakukan oleh negara lain dalam wilayah Negara Indonesia apabila tidak memperhatikan kaedah aturanaturan perundang-undangan dapat dikategorikan merupakan perbuatan melawan hukum yang diatur dalam KUHP. Moeljatno mengemukakan pendapatnya bahwa peraturanperaturan hukum pidana di Indonesia sebagian besar telah termuat dalam KUHP dan peraturan perundangundangan lain, maka pandangan tentang hukum dan sifat melawan hukum materil hanya mempunyai arti dalam memperkecualikan perbuatan yang masuk dalam kualifikasi dalam undang-undang tapi tidak dianggap perbuatan pidana atau dianggap sebagai fungsi yang negatif dari sifat melawan hukum materil. (Moeljatno, 2002: 132)

Mengacu pada cakupan pengertian intelijen berdasarkan fungsinya, dalam konteks keamanan negara dan ajaran sifat melawan hukum, maka pencantuman istilah kejahatan terhadap keamanan suatu negara yang terdapat dalam Buku Ke-2 KUHP (selanjutnya disebut Buku ke-2) merupakan salah satu dari modus operasi intelijen. Modus operasi intelijen yang tercantum dalam pasal tersebut, memberikan pandangan bahwa negara sebagai objek dari pelaksanaan sasaran operasi intelijen. Beberapa pasal dalam Buku ke-2, unsur-unsur deliknya dapat dikategorikan sebagai modus operasi intelijen sebagai berikut :

\section{a) Tindak pidana menggerakkan suatu negara asing untuk melakukan tindakan-tindakan permusuhan atau suatu peperangan dengan negara}

Rumusan tindak pidana tersebut, oleh pembentuk undang-undang telah diatur dalam Pasal 111 KUHP. Menurut ketentuan yang diatur dalam Pasal VIII Angka 15 UndangUndang Nomor 1 Tahun 1946, kata "hetzij" dan "hetzij met een Indonesche vorst of volk" dalam rumusan Pasal 111 Ayat (1) KUHP diatas itu dihapus, sehingga rumusannya berbunyi,"Barang siapa mengadakan saling pengertian dengan suatu negara asing dengan maksud untuk menggerakkanya melakukan tindakan-tindakan permusuhan atau suatu peperangan terhadap negara, lebih memperkuat 
niatnya yang telah ada untuk melakukan tindakan-tindakan seperti itu, menjanjikan bantuannya kepada mereka atau membantu persiapan untuk melakukan tindakan-tindakan tersebut, dipidana dengan pidana penjara selama-lamanya lima belas tahun, dan ayat menyebutkan,"jika tindakantindakan permusuhan itu benar-benar dilakukan atau peperangan itu benarbenar terjadi, dijatuhkanlah pidana mati atau pidana seumur hidup atau pidana penjara selama-lamanya dua puluh tahun". (Lamintang, 1987: 103) Berdasarkan rumusan pasal tersebut diatas, dapat diketahui bahwa tindak pidana memiliki unsur delik sebagai berikut :

1) Unsur Subyektif

Unsur Subyektif yaitu "dengan maksud". Kata "dengan maksud" menunjukkan bahwa unsur-unsur yang terletak di belakang kata tersebut, semuanya diliputi dengan maksud dari pelaku, sehingga unsurunsur itu harus di dakwakan terhadap terdakwa dan dibuktikan di depan sidang pengadilan ketika memeriksa terdakwa. (Lamintang, 1987 : 103) Penjabaran kata "dengan maksud" dalam rumusan pasal tersebut, dikuatkan juga oleh Adami Chazawi dengan menyatakan bahwa salah satu dari unsur-unsur tersebut apabila tidak terbukti salah satu, akan menyebabkan hakim memberikan putusan bebas atau vrijspraak untuk terdakwa. (Adami Chazawi, 2002: 58)

\section{2) Unsur Obyektif}

Unsur Obyektif dalam pasal ini yaitu mengadakan saling pengertian, atau dengan suatu negara asing, atau menggerakkan mereka, atau untuk melakukan tindakan-tindakan dan permusuhan atau untuk melakukan peperangan atau terhadap negara atau lebih memperkuat niat mereka yang sudah ada, atau menjanjikan bantuannya kepada mereka atau memberikan bantuannya dalam mempersiapkannya.

Berdasarkan uraian delik-delik tersebut diatas, Penulis berpendapat bahwa jenis tindak pidana ini merupakan kegiatan operasi intelijen tertutup yang disebut Subversi Asing. AC Manulang memberikan pengertian bahwa yang dimaksud dengan Subversi Asing adalah salah satu bentuk kegiatan intelijen yang 
bersumber dari negara asing untuk kepentingan nasional di negara akreditasi. (AC Manulang, 2001: 2531) Contoh dari pengertian Subversi Asing misalkan, staf kedutaan negara asing secara rahasia, melakukan kegiatan intelijen dengan sasaran mempertentangkan antara agama dan ideologi untuk memperluas pengaruh, merebut kekuasaan atau menggulingkan pemerintahan yang sah dengan cara yang umum merekrut penduduk setempat untuk menciptakan keresahan ditengah masyarakat.

b) Tindak mengumumkan menyerahkan berita-berita atau kete keterangan kepada negara asing, yang kerahasiannya harus dijaga demi kepentingan negara

Rumusan tindak pidana ini diatur dalam Pasal 112 KUHP. Ketentuan dalam pasal ini memiliki unsur delik antara lain :

1) Unsur Subyektif

Unsur Subyektif terdiri dari kata "Dengan sengaja" atau "Atau yang ia ketahui".

2) Unsur Obyektif
Unsur Obyektif terdiri dari "Mengumumkan, atau surat-surat, berita-berita atau keteranganketerangan, mengenai suatu hal, atau yang kerahasiannya harus dijaga demi kepentingan negara, atau memberitahukan atau menyerahkan atau kepada suatu negara asing”.

Ditinjau dari penempatan di dalam perumusan tindak pidana, maka unsur-unsur yang terletak di belakang kata "opzettelijk" tersebut, semuanya diliputi oleh "opzet" yang artinya semua unsur tersebut harus di dakwakan terhadap terdakwa dan dapat dibuktikan di sidang pengadilan. (Adam Chazawi, 2002 : 76) Lamintang menambahkan bahwa kata-kata "waarvan hij weet" merupakan kata lain yang pada umumnya dipakai oleh pembentuk undang-undang untuk menentukan bahwa perbuatan tersebut disyaratkan sebagai harus dilakukan dengan sengaja. Kesengajaan mengumumkan surat-surat, beritaberita atau keterangan-keterangan mengenai suatu hal yang kerhasiannya harus dijaga demi kepentingan negara. (Lamintang, 1984: 120) Pasal 112 KUHP 
melarang dua macam perbuatan masing-masing yakni, mengumumkan (openbaar maken) surat-surat, atau berita-berita atau keterangan-keterangan mengenai suatu hal, yang kerahasiannya diketahui harus dijaga demi kepentingan negara dan memberitahukan ataupun menyerahkan secara sembunyisembunyi surat-surat, berita-berita atau keterangan-keterangan mengenai suatu hal, yang kerahasiannya harus dijaga demi kepentingan negara.

Berdasarkan uraian delik tersebut, Penulis berpendapat jenis kegiatan intelijen yang dapat dikategorikan sebagai tindak pidana dalam pasal ini yaitu :

1) Propaganda

Propaganda menurut AC Manulang dalam buku yang sama, adalah usaha mempengaruhi pendapat umum dan mengalihkan pada tujuan tertentu dengan menggunakan sarana komunikasi seperti media massa. AC Manulang juga menekankan bahwa kegiatan propaganda tidak terlepas dari usaha mengindoktrinasi orang lain sehingga isu yang muncul dan diulang-ulang dipaksa menjadi kebenaran

2) Sabotase

Sabotase masih menurut pengertian AC Manulang, adalah tindakan menghancurkan, mengacaukan, merintangi dan menghambat pelaksanaan suatu rencana yang sedang berjalan atau diketahui secara indikatif akan berjalan dari suatu gerakan operasi pihak lawan atau lembaga intelijen yang menjadi sasarannya.

3) Spionase

Mengutip dari AC Manulang, Spionase adalah suatu gerakan intelijen yang tertutup dengan menggunakan berbagai cara untuk memperoleh baket (informasi/data) yang lebih otentik, cara tersebut diantaranya memperoleh baket secara perorangan, dilakukan secara bersama-sama yang dikoordinasikan dalam tim menurut kebutuhan, membangun jaringan dan perangkat negara terakreditasi, jaringan operasi intelijen yang terkendali, menyusupkan seseorang atau lebih kepada pihak lawan, bekerjasama dengan pihak-pihak bertentangan 
dalam pekerjaan memperoleh baket yang sama.

\section{Adami Chazawi juga} menambahkan, bahwa unsur delik "in handen worden gespeld" atau disampaikannya rahasia-rahasia negara asing itu, saat ini dapat dilakukan dengan perantaraan salah seorang anggota dari bermacammacam misi yang dikirimkan oleh negara-negara asing ke Indonesia, misalnya misi perdagangan, misi kebudayaan, misi ke-olahragaan, misi persahabatan. Fakta yang lebih jelas tentunya melalui misi diplomatik, yakni dengan diserahkannya keteranganketerangan yang harus dirahasiakan demi kepentingan negara kepada salah seorang pejabat dari suatu kedutaan besar asing yang berada di Jakarta.

c) Tindak pidana kesengajaan mengumumkan, memberitahukan menyampaikan surat-surat rahasia, peta-peta, rencanarencana dan lain-lain yang berhubungan dengan pertahanan atau dengan kemanan luar negara Indonesia kepada orang-orang yang tidak berwenang mengetahuinya
Terdapat dalam Pasal 113 KUHP, rumusan di dalam Bahasa Belanda setelah dirubah dengan ordanansi tanggal 22 September 1945, Staatbald 1945 Nomor 135, yang menyebutkan, "Barangsiapa menguasai surat-surat rahasia, petapeta, rencana-rencana, gambargambar atau alat-alat, yang berhubungan dengan pertahanan atau dengan keamanan keluar negara Indonesia, atau mengetahui isi dari surat-surat rahasia atau bentukbentuk dan susunan dari alat-alat rahasia itu, dengan sengaja mengumumkan seluruh atau sebagian surat-surat atau alat-alat tersebut, atau isinya, bentuk dan susunannya, ataupun memberitahukan atau menyerahkannya kepada orang lain yang tidak berwenang mengetahuinya, dipidana dengan pidana mati atau dengan pidana penjara seumur hidup dengan pidana penjara sementara selama-lamanya dua puluh tahun". (Lamintang, 1984: 132)

Kata "dengan sengaja" dalam rumusan tindak pidana dalam Pasal 113 KUHP harus diartikan secara 
luas. (Lamintang, 1984 : 133) Unsurunsur kesengajaan secara keseluruhan harus didakwakan oleh penuntut umum di dalam surat dakwaan dan dibuktikan di sidang pengadilan bahwa unsur-unsur tersebut telah dipenuhi oleh terdakwa. Adanya hubungan dengan tindakan-tindakan yang terlarang dalam rumusan Pasal 113, agar terdakwa dapat dinyatakan terbukti melakukan tindakan-tindakan tersebut dalam sidang pengadilan harus dapat dibuktikan, bahwa terdakwa telah menghendaki untuk mengumumkan, memberitahukan atau menyerahkan surat-surat rahasia, peta-peta dan lain-lain yang berhubungan dengan pertahanan negara atau dengan pengamanan keluar negara Indonesia, yang ia kuasai atau yang ia ketahui tentang isi, bentuk atau susunannya, kepada orang-orang lain yang tidak berwenang untuk mengetahuinya. Sedangkan untuk unsur obyektif, penuntut umum harus membuktikan bahwa terdakwa mengetahui bahwa isi yang terkandung didalamnya kategori rahasia. Contoh dari uraian delik ini adalah pada tahun 1975 seorang anggota Angkatan Bersenjata Republik Indonesia (ABRI) dengan pangkat Letnan Kolonel berinisial "S", telah menyerahkan keterangan-keterangan tertentu yang ada hubungannya dengan pertahanan Negara Indonesia, kepada direktur perwakilan perusahaan penerbangan Aeroflot, yang ternayata merupakan seorang anggota KGB (Badan Intelijen Uni Soviet) (Lamintang, 1984 : 138) Di negara asalnya yaitu Belanda, Pasal 113 KUHP diatur dengan Pasal 98 W.v.S, dengan terbentuknya undang-undang tanggal 5 April 1951 tentang perlindungan rahasia-rahasia negara, staatbald Tahun 1951 No. 52, kemudian telah diubah dalam W.v.S telah ditambahkan tiga pasal baru yakni pasal 98a-98c.

Perintah Undang-Undang, Jabatan Serta Pernyataan Dalam KUHP dan Pembuktian dalam KUHAP Sebagai Faktor Tidak Dapat Dipidanakannya Kegiatan atau Operasi Intelijen

Dalam banyak kejadian, operasi intelijen negara yang dilakukan oleh suatu aparat intelijen, tidak dapat 
dimintai pertanggungjawaban hukum pidana dikarenakan ada beberapa aspek pengecualian. Beberapa modus operasi intelijen dari kasus yang pernah terjadi memang termasuk dalam rumusan delik dalam KUHP, akan tetapi di bab yang lain juga memberikan pengecualian dengan alasan peniadaan hukuman dan penuntutan. KUHP pada prinsipnya mengatur hanya pada tanggung jawab individu bukan tanggung jawab institusi. Sehingga dalam konteks tanggungjawab komando, KUHP tidak dapat diberlakukan karena KUHP itu sendiri membebaskan pelaku kejahatan karena adanya perintah atasan atau komando. Terdapat perbedaan penggunaan istilah antara dasar peniadaan dengan dasar meniadakan hukum. Lamintang dalam bukunya halaman 368 menjelaskan bahwa yang dimaksud dari dasar peniadaan hukuman adalah keadaan-keadaan yang membuat hakim tidak dapat mengadili seorang pelaku sehingga hakim tidak dapat menjatuhkan suatu hukuman terhadap pelaku tersebut, sedangkan peniadaan penuntutan adalah keadaan-keadaan yang membuat penuntut umum tidak dapat melakukan suatu penuntutan terhadap seorang pelaku. Dasar-dasar meniadakan penuntutan terdapat dalam Buku Ke-1 KUHP dalam Bab VII dan Bab VIII Pasal 76, 77, dan 82. Sedangkan dasar-dasar meniadakan hukuman tercantum dalam Buku ke-1 KUHP diatur dalam Bab III Pasal 44, 48, 49 ayat (2), 50, 51, Bab V Pasal 59.

Aparat intelijen negara yang menjalankan operasi intelijen, Penulis berpendapat tidak dapat dikualifikasikan dalam rumusan delik pidana dikarenakan menjalankan perintah undangundang sesuai Pasal 50 KUHP dan menjalankan perintah jabatan sesuai Pasal 51 KUHP. Pendapat Penulis ini dikuatkan oleh Simons dalam bukunya Lamintang halaman 487 yang menyatakan bahwa menurut hukum yang berlaku di Indonesia, tindakan-tindakan yang telah dilakukan orang untuk melaksanakan suatu peraturan perundang-undangan atau suatu perintah jabatan tidak bersifat melanggar hukum dan oleh karena itu tidak menyebabkan orang tersebut dijatuhi suatu hukuman. 
Pakar Hukum Belanda Van Hattum juga memberikan pendapat bahwa tidak dapat dihukumnya seorang yang telah melakukan suatu perbuatan untuk melaksanakan suatu peraturan perundang-undangan tidak ada hubungannya dengan tidak adanya suatu kesalahan (schuld) pada orang yang telah melakukan perbuatan tersebut, melainkan perbuatan itu sendiri tidak memiliki sifat wederrechtelijk. (Lamintang, 1984 : 258). Van Hattum selanjutnya memberikan suatu gambaran yaitu sesorang di satu sisi tidak boleh mengambil barang milik orang lain, membunuh orang lain, merusak barang orang lain, secara paksa memasuki rumah orang lain dan lainlain, namun di pihak lain seseorang juga memiliki kewajiban melaksanakan peraturan-peraturan perundang-undangan atau perintahperintah jabatan. Dalam contoh tersebut, pembentuk undang-undang pada dasarnya menyatakan apabila terdapat suatu pertentangan antara kewajiban-kewajiban dengan kepentingan-kepentingan, maka seseorang wajib mendahulukan pelaksanaan peraturan-peraturan perundang-undangan dan perintahperintah.

Peraturan perundang-undangan maupun perintah jabatan sebagai pedoman aparatur intelijen negara untuk menjalankan tugasnya, harus di definisikan secara jelas supaya segala aktifitas kegiatan tersebut dapat dipertanggungjawabkan di hadapan hukum. Namun tidak semua perintah jabatan atau perintah undang-undang merupakan kewajiban yang harus dipatuhi. Menurut Van Hammel, yang dimaksud kewajiban untuk menjalankan perintah jabatan atau undang adalah berdimensi hukum publik. (Lamintang, 1984 : 493) Paramater tertentu menurut Hazewinkel dan Suringa juga bisa digunakan acuan terkait batasan tindakan-tindakan aparatur intelijen negara sehingga tidak dapat dikategorikan tindak pidana, yaitu dapat dilihat dari sarana-sarana atau alat-alat yang sesuai atau yang pantas dipergunakan oleh orang itu (Lamintang, 1984 : 203). Dalam konteks yang lain, Pompe menjelaskan bahwa suatu instruksi memuat sejumlah perintah tidak 
hanya sebatas peristiwa-peristiwa konkret yang bersifat tertentu, maka dari itu instruksi-instruksi jabatan dapat dimasukkan ke dalam pengertian perintah jabatan dalam Pasal 51 KUHP. (Lamintang, 1984 : 507) Kasus terbunuhnya aktivis Hak Asasi Manusia (HAM) Munir Said Thalib pada tahun 2004 merupakan salah satu bentuk tindakan operasi intelijen yang dilakukan oleh negara terhadap warga negara sendiri. Penulis berpendapat demikian dikarenakan aktor utama dibalik terbunuhnya Munir masih belum jelas dan sanksi yang diberikan lebih bersifat "kesalahan prosedural". Hal ini dapat dilihat dari pasal yang didakwakan oleh Pollycarpus Budihari Priyanto (Pollycarpus) yaitu Pasal 340 KUHP jo Pasal 55 Ayat (1) KUHP sedangkan di tempat yang lain Muchdi Purwopranjono (Muchdi PR) dijerat dengan Pasal 55 Ayat (1) ke-2 jo Pasal 340 KUHP. Putusan Kasasi No. 1185 K/Pid/2006 menyatakan bahwa Terdakwa Pollycarpus hanya diputus bersalah melakukan tindak pidana surat palsu dalam Pasal 263 Ayat (2) KUHP dengan pidana dua tahun sekaligus membatalkan putusan tingkat Pengadilan Negeri (PN) dan Pengadilan Tinggi (PT) yaitu Pasal 340 jo Pasal 55 Ayat (1) KUHP. (Usman Hamid, 2007 : 253)

\section{Rudi Satrio Mukantardjo} memberikan pendapat atas putusan kasasi tersebut dengan menyatakan terdapat kesamaan dalam dakwaan yang diancamkan oleh Jaksa Penuntut Umum (JPU) yaitu selalu mencantumkan Pasal 55 Ayat (1) ke1 KUHP dalam dakwaan satu maupun dua. Pasal 55 Ayat (1) ke-1 menyatakan bahwa seseorang dapat dipidana sebagai pembuat (dader) yaitu mereka melakukan, yang menyuruh lakukan dan yang turut serta melakukan perbuatan. Dalam kajian hukum pidana, apabila terhadap seseorang disangka melakukan tindak pidana (pembunuhan dan penggunaan surat palsu) dan selanjutnya di-juncto-kan dengan Pasal 55 KUHP, maka tersangka melakukan tindak pidana tersebut tidak sendirian. (Usman Hamid, 2007 : 253) Maka dari itu, penulis berpendapat pelaku dalam kasus pembunuhan Munir, dilakukan oleh lebih dari satu orang atau 
dilakukan dengan peran-peran berbeda. Bahkan terhadap putusan kasasi kasus ini, internal Mahkamah Agung (MA) melakukan eksaminasi putusan yang hasilnya bahwa sebelum kejadian pembunuhan, ada hubungan antara Pollycarpus dengan petinggi (salah satunya Muchdi PR) dalam pesan singkat maupun sambungan telephon serta keterangan saksi-saksi. MA juga menekankan bahwa majelis hakim dan JPU yang memeriksa terdakwa saat agenda pembuktian di persidangan, tidak menggali lebih jauh bahkan cenderung mereduksi fakta-fakta yang terdapat dalam persidangan. (Usman Hamid, 2007 : 276-277)

KUHAP sebagai hukum acara hukum pidana itu sendiri, juga mengatur metode pembuktian di persidangan. Namun dalam kasuskasus yang melibatkan operasi intelijen negara yang tidak sesuai prosedur, Pasal 170, 183 dan 184 KUHAP yang harusnya menjadi "trigger" menegakkan kebenaran materiil, tidak dapat berjalan karena memiliki beberapa kelemahan. Satu diantara kelemahan tersebut adalah bahwa pemeriksaan alat-alat bukti tersebut harus dilakukan dipersidangan dan cara untuk memperoleh alat-alat bukti tersebut harus dibenarkan hukum. Sebagai contoh misalkan alat bukti saksi atau surat. Aparat intelijen yang diminta untuk bersaksi di hadapan majelis hakim dapat memberikan keterangan yang "sekedarnya" dengan dalih memegang rahasia negara pun juga dokumen surat yang diperiksa tidak dapat diperiksa karena merupakan dokumen yang bersifat rahasia.

\section{Konsep Pengawasan Kegiatan Intelijen dan Perlindungan Hukum}

Konsep pengaturan kegiatan Intelijen di beberapa negara seperti Kanada, Korea Selatan dan Amerika Serikat tidak hanya terfokus pada struktur organisasi, namun sudah membahas tentang kewenangan, kerahasiaan, bahkan kesejahteraan serta perlindungan hukum. (Alexandra Retno Wulan, 2006 : 7) Negara-negara dengan sistem hukum Common Law seperti Inggris, Kanada, Malaysia, Singapura dan Australia memiliki titik berat kontrol di aspek hukum dan parlemen 
sedangkan negara-negara Civil Law lebih menekankan pada pengawasan parlemen meskipun Amerika Serikat memadukan pengawasan Yudikatif, Eksekutif dan Parlemen. (Soedjati Djiwandono, 2005 : 78-79) Indonesia sebagai salah satu negara yang menjadikan hukum sebagai parameter penegakan hukum dan keadilan belum memiliki paying hukum yang jelas terhadap keberadaan aktifitas intelijen luar maupun dalam. UUIN hanya sebatas mengatur masalah wadah / organisasi sedangkan kewenangan, batasan dan perlindungan hukum masih belum jelas diatur. Keberadaan UU Intelijen (baca Internal Security Act sama hal nya di Malaysia maupun Singapura) berikut dukungan revisi KUHAP maupun KUHP sangat dibutuhkan demi menjaga marwah Indonesia sebagai Negara Hukum bukan kekuasaan absolut.

\section{Simpulan}

Kegiatan intelijen yang dilakukan oleh dinas intelijen atau badan intelijen negara terdiri intelijen ke dalam dan ke luar negara. Pembagian ini harus dilakukan mengingat tujuan serta pola yang digunakan untuk mengamankan kepentingan negara berbeda. Kegiatan intelijen dapat dilakukan dengan sarana atau bentuk antara lain sumber intelijen, propaganda, sabotase, kontra sabotase, spionase dan intelijen pengamanan. Operasi intelijen bersifat tertutup bersifat subversi asing, subversi local, subversi domestik, operasi intelijen terbuka, operasi intelijen tersamar, penggalangan, kegiatan tertutup dan kegiatan rahasia non-diplomat. Pola kegiatan intelijen luar tersebut pada dasarnya dapat memenuhi kualifikasi delik tindak pidana yang diatur dalam Pasal 104, 107, 108, 111, 112 , 113, 114, 115, 131, 162 dan 163 bis KUHP. Dalam konteks, kegiatan Intelijen ke dalam, masih belum terdapat batasan-batasan hukum yang dapat digunakan sebagai tolak ukur suatu kegiatan intelijen adalah sesuai dengan koridor yang telah ditetapkan. Pasal 50 dan 51 KUHP tentang perintah jabatan dan undangundang, serta Pasal 55 KUHP tentang Penyertaan menjadi salah satu dasar hukum tindakan yang dikualifikasikan sebagai kegiatan 
atau operasi intelijen tidak dapat dikenai sanksi pidana. KUHAP sebagai pelaksanaan hukum pidana materiil yang memiliki metode pembuktian cermat, teliti, terbuka (prinsip umum), dan valid sangat bertolak belakang dengan pola-pola kegiatan intelijen yang bersifat tertutup atau rahasia. Pengawasan kegiatan intelijen di beberapa negara baik "Common Law" maupun "Civil Law" melibatkan "stakeholder" negara itu sendiri yaitu control yudikatif, eksekutif dan legislatif. Di Era Industri 4.1, perang tidak lagi dan tidak hanya menggunakan sistem persenjataan militer namun juga "proxy war". Pengaturan batasanbatasan dan perlindungan hukum baik untuk kegiatan intelijen ke dalam maupun ke luar, merupakan suatu keharusan negara untuk menjaga kedaulatan negara berserta hukum itu sendiri.

\section{Daftar Pustaka}

\section{Buku}

Chazawi, Adami. 2002. Kejahatan Terhadap Keamanan dan Keselamatan Negara. Jakarta: Raja Grafindo Persada.
Djiwandono, Soedjati. 2005. Pengawasan Parlemen Dalam Sektor Keamanan. Jakarta: CSIS.

Hamid, Usman, dkk. 2007. Risalah Kasus Munir: Kumpulan Catatan dan Dokumen. Jakarta: KASUM dan CV Rinam Antartika.

Ibrahim, Johnny. 2006. Teori dan Metodologi Penelitian Hukum Normatif, Malang: Bayu Media Publishing.

Karjadi. 2009. Intelijen Pengawasan Terhadap Negara. Jakarta: Politea.

Lamintang. 1984. Dasar-Dasar Hukum Pidana Indonesia. Bandung: Sinar Baru.

\begin{tabular}{lr} 
1984. Kitab & Undang- \\
\hline Undang Hukum Pidana \\
dengan Pembahasan & secara \\
Yurisprudensi dan Ilmu \\
Pengetahuan \\
Bandung: Sinar Baru.
\end{tabular}
1987. Delik-Delik Khusus Kejahatan Terhadap Kepentingan Hukum Negara. Bandung: Sinar Baru.

Manulang, AC. 2001. Menguak Tabu Intelejen Teror Motif dan Rezim. Jakarta: Phanta Rei.

Marzuki, Peter Mahmud. 2005. Penelitian Hukum, Jakarta: Prenada Media.

Moeljatno, 2002. Asas-Asas Hukum Pidana. Jakarta: Rineka Cipta. 
Sudarto. 1990. Hukum Pidana I. Semarang: Yayasan Sudarto dkk Fakultas Hukum Universitas Diponegoro.

Sutopo, FX. 2008. Dinamika Intelijen Dunia. Yogyakarta: Garasi.

Wardaya, Baskara T. 2006. Bung Karno Menggugat. Jakarta: Yayasan Obor Indonesia.

\section{Jurnal}

Anggoro, Kusnanto. 2005. Konsolidasi Negara Transisi Politik dan Fungsi Intelijen. Jakarta: PACIVIS Center for Global Society Studies Universitas Indonesia.

Wulan, Alexandra Retno, dkk. 2006. Negara Intel dan Ketakutan. Jakarta: PACIVIS Center for Global Society Studies Universitas Indonesia. 